Elena Bykova*, Yuliya Shabayeva*

\title{
Comparative Analysis of Results of Cadastral Land Valuation and Real Market Environment in Saint Petersburg
}

\begin{abstract}
An analysis of the results of cadastral land valuation in Saint Petersburg is presented in this article. Cadastral values are compared with the real market prices of land plots. This allowed us to justify the need to take into account the isolation of pricing processes in the identified zones for the calculation of land tax.
\end{abstract}

Keywords: land valuation, real estate market, statistical analysis, market price, cadastral value

\footnotetext{
* Saint Petersburg Mining University, Department of Engineering Geodesy, Saint Petersburg, Russia
} 


\section{Introduction}

Well-balanced planning of regional budget income as well as the efficient and reasonable management of land resources in urban territories require the methodologically correct assessment of cadastral land value in populated places, as it is the basis for calculating land tax.

In the context of social and economic development, the increase in intensity of urbanization, and consecutive social stratification among the population, prestige areas are formed within urban territories depending on the social, economic, spatial, and environmental conditions. As analysis shows their distinctive features include isolated price-forming processes and the difference in prices for immovable property. The prices for land plots intended for individual residential development in Saint Petersburg vary from 1000 to $26,000 \mathrm{RUB} / \mathrm{m}^{2}$ However, methodological basis for the public cadastral valuation of lands does not take the current price differentiation into account, which results in establishing an economically unjust level of land tax. This may particularly lead to a reduced cadastral value of lands in prestigious districts and a significant overestimation of land plots in non-prestigious territories as related to their market prices.

Furthermore, abolition of the Technical Recommendations for the public cadastral valuation of lands in populated locations resulted in cancelling the exemplary list of land plot value drivers, which promoted some subjectivity in determining their structure by the valuation authorities.

Issues related to improving the methodology for land cadastral valuation have been studied by such scientists as S.V. Gribovskiy [1], A.V. Sevostyanov [2, 3], V.A. Prorvich [4], A.A. Varlamov [3], A.D. Vlasov [5], J. Kuryj and O. Kuryj-Wysocka [6], J. Kuryj and R. Źróbek [7], among others. Basic theoretical and methodological aspects of immovable property valuation are described in the works of J.K. Eckert [8], V. Petty, A. Smith, D. Ricardo [9], T. Copeland, J. Murrin [10], and J. Friedman [11]. Evaluation of the prestige and reputation of certain city districts in order to ensure the complete and adequate consideration of value drivers is mentioned in the works of O.M. Vandanimayeva [12], I.H. Nanazashvili [13], and A.P. Romm [14, 15]. Nevertheless, despite all of the existing scientific undertakings in the field under study, there currently are no conceptual nor methodological approaches to determine the prestige of territories for the sake of the cadastral valuation of urban lands.

It is evident that modifying the existing methodology for individual residential development land valuation by taking into account urban space differentiation in terms of prestige is currently a relevant scientific task; its solution will increase the objectivity of cadastral valuation and eliminate the issue of social injustice in taxation. Segregation of prestige areas will allow us to analyze the spatial structure of the city and take measures to increase the investment climate in its territories. 


\section{Current Model of Cadastral Land Valuation in Saint Petersburg}

In accordance with the Russian Government Decree No. 316 of April 8, 2000, "On Approving the Rules for Public Cadastral Valuation of Lands," the public valuation of lands shall be undertaken at least once every five years. The previous public cadastral valuation of Saint Petersburg lands was performed in 2013, and its results were approved by the Decree of the Committee for Land Resources and Land Planning of Saint Petersburg of October 17, 2013 (No. 365).

According to the cadastral valuation report for the lands of Saint Petersburg (report) [16], the cadastral land value intended for low-rise residential houses (including individual residential development - Permitted Use 2) is influenced by the following drivers: area, trunk roads, local centers, engineering provisioning, atmosphere pollution, green areas, and proximity to water bodies.

It should be noted that the results of the experimental studies conducted by the authors have shown that these factors (along with some others) were among the most relevant ones.

In order to build a model for Permitted Use 2 land plot cadastral valuation, 609 information units were used on their market price. The final model represents a multiplicative (indicative) dependence of the cadastral value on the indices of price forming factors [17]:

$$
\mathrm{KC}=\mathrm{KC}_{\text {base }} \cdot K_{\text {area }} \cdot K_{\text {location }} \cdot K_{\text {engineering }} \cdot K_{\text {atm_pol }} \cdot K_{\text {green }} \cdot K_{\text {water }} \cdot K_{\text {social }}
$$

where:

$$
\begin{aligned}
K C_{\text {base }} & \text { - base rate }\left(3491 \mathrm{RUB} / \mathrm{m}^{2}\right), \\
K_{\text {area }} & - \text { coefficient of area, } \\
K_{\text {location }} & - \text { coefficient of location about trunk roads and local centers, } \\
K_{\text {engineering }} & - \text { coefficient of engineering provisioning, } \\
K_{\text {atm_pol }} & - \text { coefficient of atmosphere pollution, } \\
K_{\text {green }} & - \text { coefficient of green areas, } \\
K_{\text {water }} & - \text { coefficient of proximity to water bodies, } \\
K_{\text {social }} & - \text { coefficient of social infrastructure. }
\end{aligned}
$$

Each factor was converted by using an exponential (town-planning) function until obtaining the best-quality model.

Relevance indicators of the regression equation obtained by the modeling are listed in Table 1.

According to the modeling results, $78 \%$ of the dependent variable variations were considered in the model and caused by the included variables, which indicates a strong link between the response and factors against the Chaddock scale. The report also contains analysis graphs of the model's random component, whose data 
corresponds to the normal distribution law and observation of the homoscedasticity condition. Thus, the values of the quality model indicators given in the report show its acceptable quality and statistic relevance.

Table 1. Regression statistics for the permitted use two model

\begin{tabular}{||l|c||}
\hline \multicolumn{1}{|c|}{ Indicator } & Indicator's value \\
\hline \hline Coefficient of determination $R^{2}$ & 0.786 \\
\hline$R^{2}{ }_{\text {ADJ }}$ & 0.782 \\
\hline$F$-statistics & 219.67 \\
\hline$F($ table $)$ & 1692 \\
\hline RMS error & 0.308 \\
\hline Approximation mean error $A[\%]$ & 3108 \\
\hline
\end{tabular}

\section{Comparative Analysis of Current Results of Cadastral Land Valuation and Market Environment in Saint Petersburg}

It should be noted that, in accordance with the applicable law, the building of models for the cadastral value calculation of land plots in populated places shall be performed on the basis of their market price, so one of the most important indices of the correct valuation is comparing market prices with the levels of cadastral value. For their comparative analysis, the maps were built to distribute the cadastral values and market prices of land plots intended for individual residential development (Permitted Use 2) calculated as the results of Public Cadastral Valuation of Lands and as the results of an analysis of the real market environment of populated places in Saint Petersburg in 2013 [17] (Figs. 1, 2 on the intereaf). In order to analyze the market prices, more than 1000 land plots were used.

In order to improve the comparability of the results and facilitate the comparative analysis of the cadastral valuation results and market prices of land plots, the number of intervals used was equal.

The resulted price maps (Figs. 1, 2) allowed for a comparative analysis that revealed problematic territories whose cadastral values are less or more than the market price (Tab. 2).

According to Table 2, we can see that the areas with a maximum difference between the market and cadastral values are mainly located within the Kurortny, Primorsky, Vyborgsky, Kolpinsky, and Krasnoselsky districts. It should be noted that the territories of these districts also belong to prestigious and non-prestigious zones, respectively, in accordance with the study undertaken by the authors. 


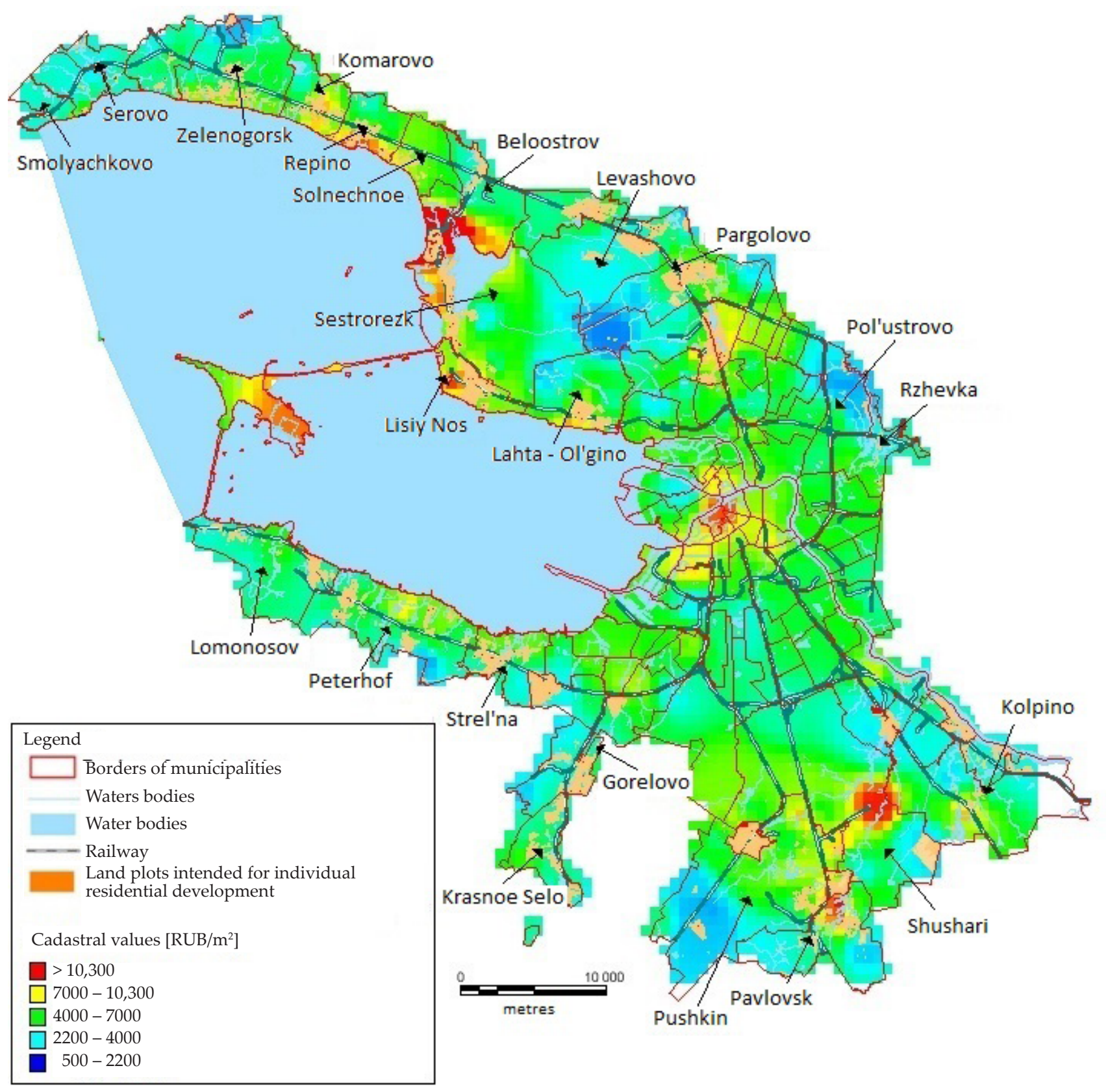

Fig. 1. Thematic map of distributing cadastral values of land plots intended for individual residential development

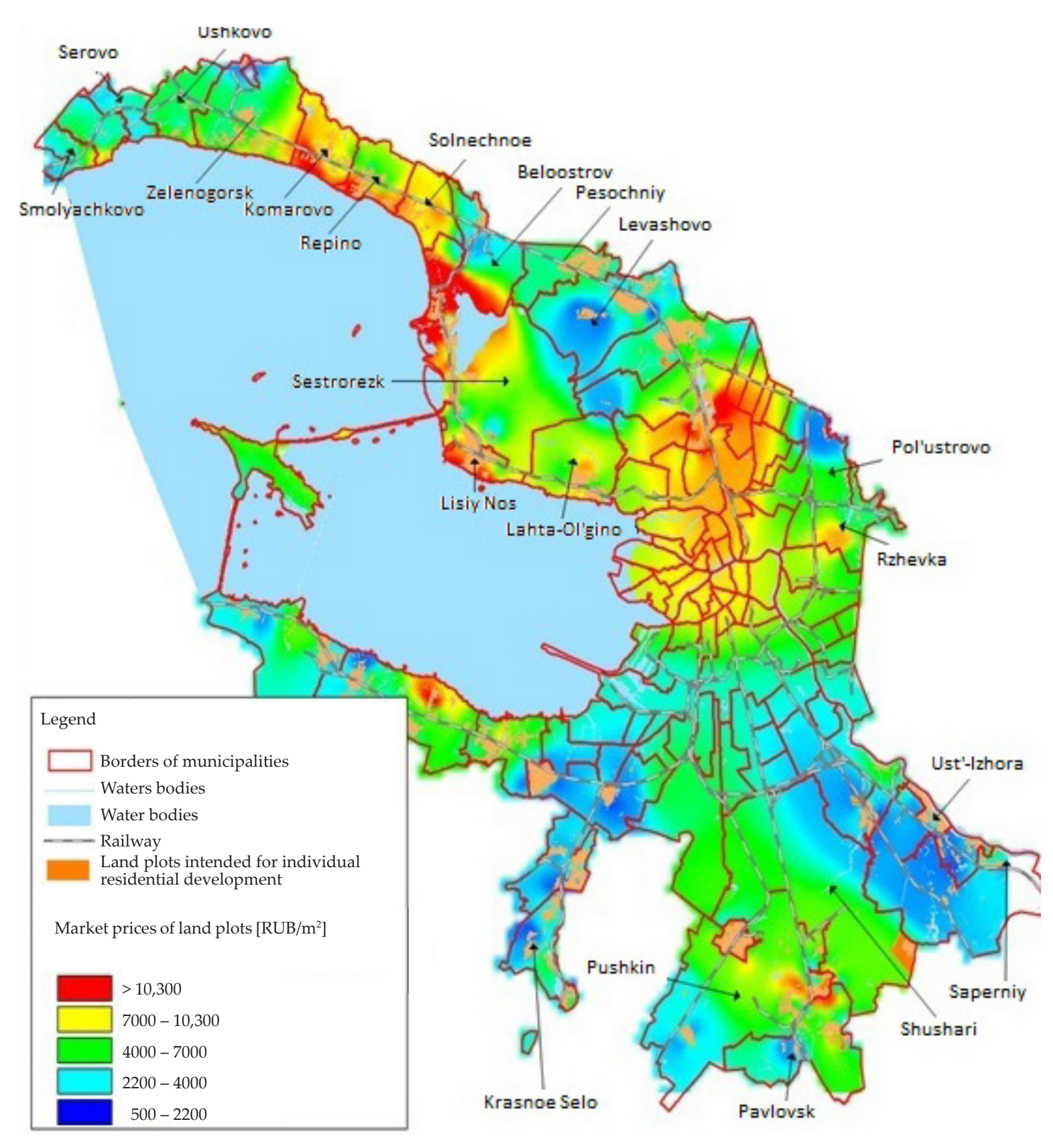
Fig. 2. Thematic map of distributing market prices of land plots intended
for individual residential development 
Table 2. Comparative analysis of cadastral value and market prices of lands

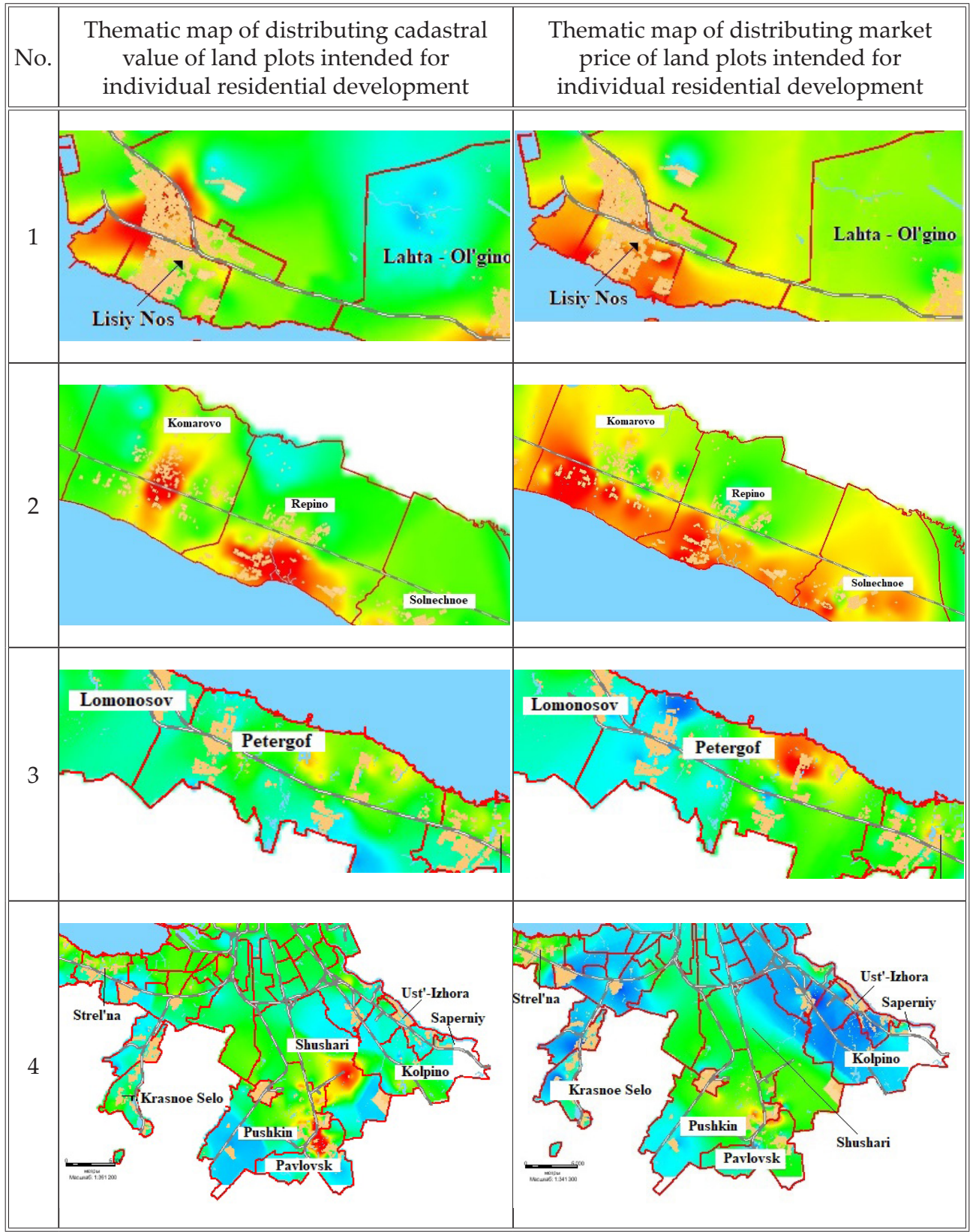

A difference analysis for the cadastral and market value of lands intended for individual residential development located in the areas of various level of prices are represented in Figures 3-5. 


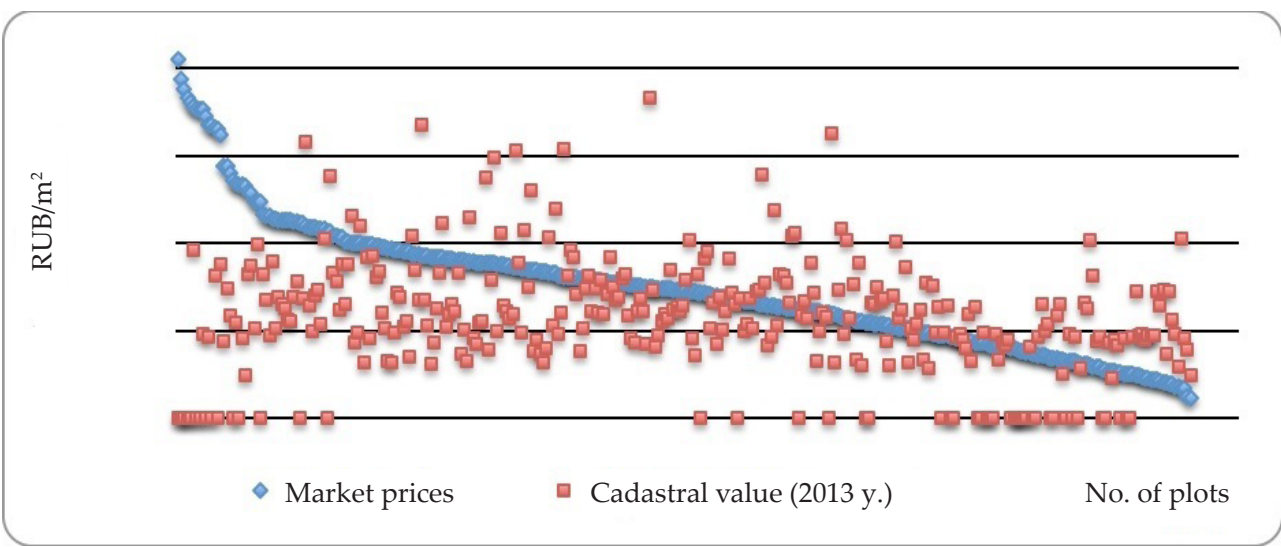

Fig. 3. Comparison of market and cadastral values of lands intended for individual residential development located in first price area

In Figures 3, we can see that the facilities of the first price area show a significant underestimation of the cadastral value, which results in budget losses in the form of undersized tax payments within the territories under consideration. Thus, the tax base is 1.3 times less than it should be.

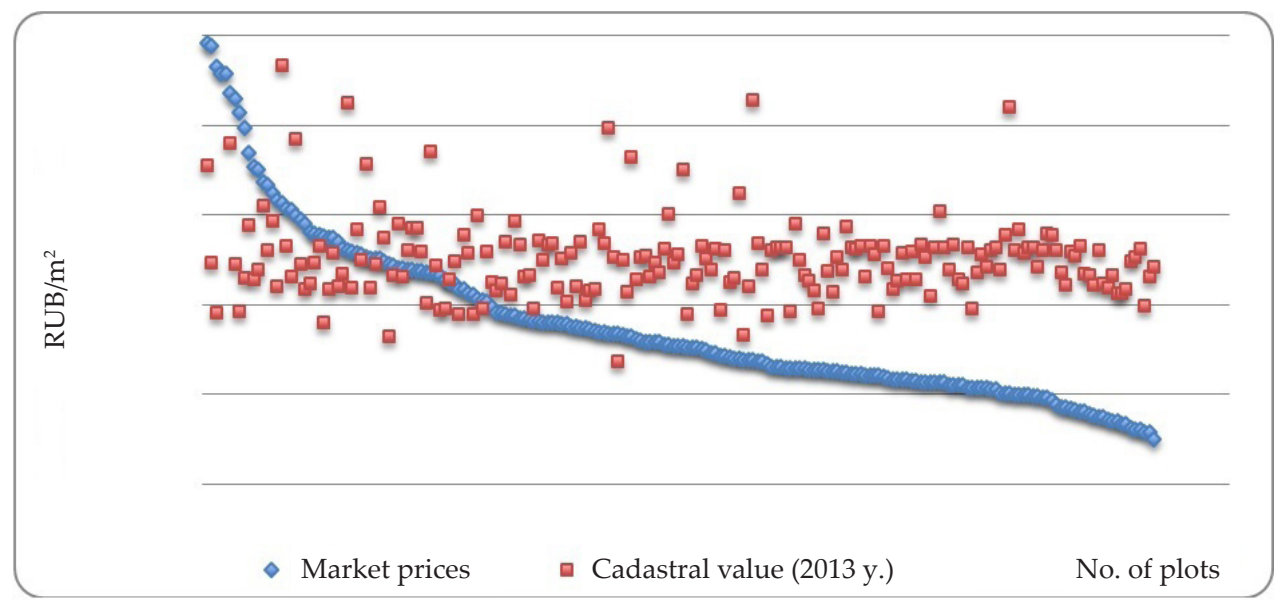

Fig. 4. Comparison of market and cadastral values of lands intended for individual residential development located in third price area

On the contrary, the third price area shows a 1.4-times-higher cadastral value as compared to the market price in accordance with the calculations (Fig. 4). The maximum surplus of cadastral value relative to the market price is more than four-fold. 
The second price area is also characterized by the overestimated cadastral value of lands (Fig. 5); however, because the difference between the price and cadastral value is both positive and negative, it's compensated and the tax base in general by 1.13 times as a whole exceeds that which should be.

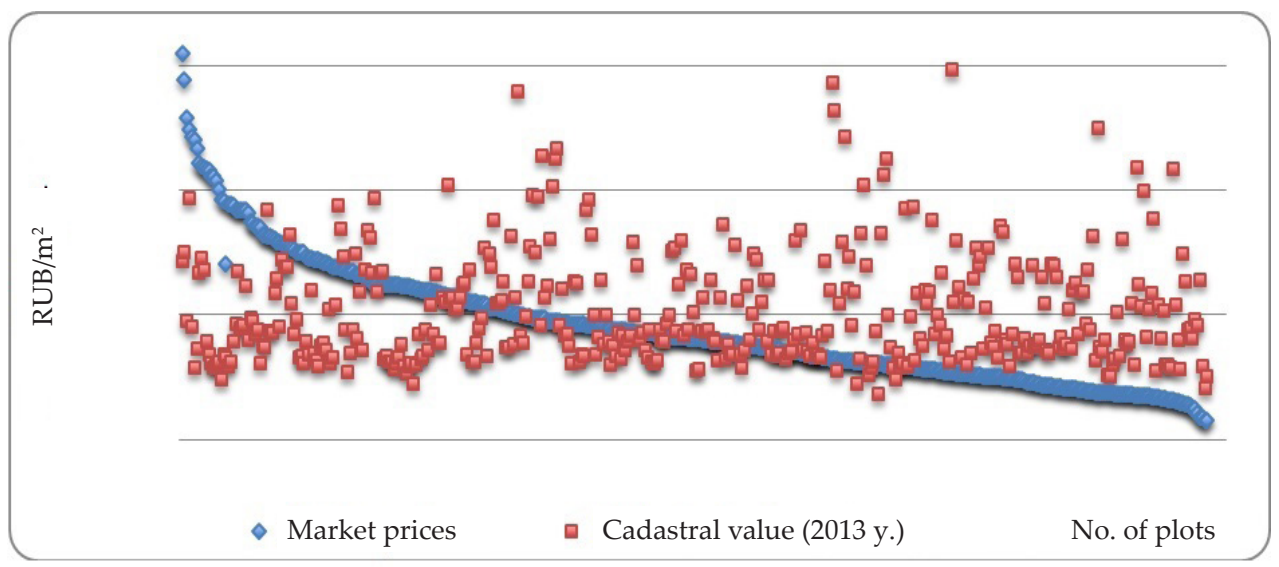

Fig. 5. Comparison of market and cadastral values of lands intended for individual residential development located in second price area

However, when comparing the sum of the cadastral and market values for the land plots from all price areas, all of the above differences are compensated. Thus, there is social injustice expressed in an underestimation of prestigious urban territories according to the public cadastral valuation 2013 results (Table 2 - Examples 1-3, Fig. 3) and an overestimation of the land plots located in non-prestigious areas (Table 2 - Example 4, Figs. 4, 5).

The differences in the prices revealed can be explained by the imperfect methods of evaluation; namely, using correlation and regression analysis for the whole territory of a large city with no grouping of lands despite the significant difference of market prices for land plots intended for individual residential development $\left(1000-26,000 \mathrm{RUB} / \mathrm{m}^{2}\right)$. This way of cadastral value modeling results in an approximation of market prices and obtaining biased cadastral values.

The relevance of this situation is emphasized by the practice of contesting the results of cadastral valuation in the Federal Service for State Registration, Cadastre, and Cartography in Saint Petersburg [16]. In all cases, an overestimation of more than $30 \%$ versus the market price was the reason for reconsidering the cadastral value of individual residential development land plots. This resulted in positive judgments towards the cadastral value of land plots being equal to their market prices determined in accordance with the provided valuation reports. 
Thus, the results of the current cadastral valuation of the permitted use of lands intended for individual residential development in Saint Petersburg show relatively low objectiveness and do not reflect the price distribution existing on the land market.

\section{Conclusions}

The results of the current cadastral valuation of Saint Petersburg lands (individual residential development) show a low objectiveness and cannot reflect the existing price distribution on the land market. In particular, the objects of the first price area are described by a significant underestimation (the market prices is averagely 1.3 times higher than the cadastral values), and in the second and third price areas, the cadastral values are averagely $40-60 \%$ higher than the market prices. This caused an assumption concerning the isolation of price-forming processes acting in various price areas; after proving this assumption, we can make some conclusions and recommendations.

First, to eliminate all of the revealed drawbacks and obtain the most-correct and objective results when the cadastral valuation of lands is intended for individual residential development, it is suggested to group land plots by ranking urban areas by prestige and model the prices separately for each area.

Secondly, the cadastral value must be modeled for each area formed under the methodology for ranking urban areas developed in $[18,19]$ due to the isolation of the price-forming processes.

Thirdly, the range of the statistically significant value factors of land plots located in various areas of prestige is different, which should be proven by the results of cadastral value modeling for individual residential development lands in Saint Petersburg.

\section{References}

[1] Gribovskiy S.V., Anisimova I.N., Barinov N.P.: Uchet raznotipnykh tsenoobrazuyushchikh faktorov $v$ mnogomernykh regressionnykh modelyakh otsenki nedvizhimosti. Voprosy otsenki, no. 2, 2004, pp. 2-16 [Грибовский С.В., Анисимова И.Н., Баринов Н.П.: Учет разнотипных цุенообразующзих факторов в многомерных регрессионных моделях оценки недвижимости, Вопросы оценки, № 2, 2004, с. 2-16].

[2] Sevost'yanov V.A., Sevost'yanov A.V., Starkov A.A.: Gosudarstvennaya kadastrovaya otsenka zemel' poseleniy: metodicheskiye ukazaniyadlya vuzov. Gosudrastvennyy universitet po zemleustroystvu, Moskva 2006 [Севостьянов B.А., Севостьянов А.В., Старков А.А.: Государственная кадастровая оценка земель поселении: методические указания для вузов. Госудраственный университет по землеустройству, Москва 2006. 
[3] Varlamov A.A., Sevost'yanov A.V.: Zemel'nyy kadastr. Tom 5: Otsenka zemli i inoy nedvizhimosti: Uchebnik dlya vuzov. Koloss, Moskva 2006 [Варламов А.А., Севостьянов А.В.: Земельный кадастр. Том 5: Оиенка земли и иной недвижилости: Учебник для вузов. Колосс, Москва 2006].

[4] Prorvich V.A.: Osnovy·ekonomicheskoy otsenki gorodskikh zemel'. Delo, Moskva [Прорвич В.А.: Основы экономической оценки городских земель. Дело, Москва 1998].

[5] Vlasov A.D.: Printsipy sovershenstvovaniya gosudarstvennoy kadastrovoy otsenki zemel' poseleniy s naseleniyem svyshe 10000 chelovek. Problemy finansov i ucheta, no. 3(9), 2005, pp. 79-80 [Власов А.Д.: Принциипь совершенствования государственной кадастровой оценки земель поселений с населением свыше 10000 человек. Проблемы финансов и учета, № 3(9), 2005, с. 79-80].

[6] Kuryj J., Kuryj-Wysocka O.: Metody doboru cech diagnostycznych do wyznaczania pól cenności i modelowania wartości katastralnej [The Selective Methods of Diagnostic Features in Determining the Real Estate Field of Value and Modelling Value of Property]. Acta Scientiarum Polonorum Administratio Locorum, no. 14(4), 2015, pp. 49-64.

[7] Kuryj J., Źróbek R.: Wartość katastralna nieruchomości w procesie modernizacji ewidencji gruntów i budynków [Cadastral Value of Real Estate in the Process of Modernization of Land Cadastre]. Acta Scientiarum Polonorum Administratio Locorum, no. 16(4), 2017, pp. 249-261.

[8] Eckert J.K., Gloudemans R.J., Almy R.R.: Property appraisal and assessment administration. International Association of Assessing Officers, University of Indiana, 1990.

[9] Petti V., Smit A., Rikardo D.: Antologiya ekonomicheskoy klassiki. MP «Ekonov», «Klyuch», Moskva 1993 [Петти В., Смит А., Рикардо Д.: Антология экономической классики. МП «Эконов», «Ключ», Москва 1993].

[10] Copeland T.E., Koller T., Murrin J.: Valuation - Measuring and Managing the Value of Companies. John Wiley \& Sons, New York 1990.

[11] Weinberg D.H., Friedman J., Mayo S.K.: Intraurban residential mobility: the role of transactions cost, market imperfections, and household disequilibrium. Journal of Urban Economics, no. 9, 1981, pp. 332-348.

[12] Vandanimayeva O.M.: Otsenka stoimostizemel'nykh uchastkov. Moskovskaya finansovo-promyshlennaya akademiya, Moskva 2005 [Ванданимаева О.М.: Оценка стоимости земельных участков. Московская финансово-промышленная академия, Москва 2005], [on-line:] http://www. refmag.ru/done/1/k/990202.htm [access: 29.01.2017].

[13] Nanazashvili I.Kh., Litovchenko V.A.: Otsenka nedvizhimosti: Uchebnoye posobiye. Arkhitektura, Moskva 2005 [Наназашвили И.Х., Аитовченко В.А.: Оценка недижимости: Учебное пособие. Архитектура, Москва 2005]. 
[14] Romm A.P.: Kadastrovaya otsenka gorodskikh zemel': metodicheskiye osnovy $i$ instrumental'nyye sredstva. Voprosy otsenki, no. 3. 1997, pp. 16-20 [Ромм А.П.: Кадастровая оценка городских земель: методические основь и инструментальные средства. Вопросы оценки, № 3. 1997, с. 16-20].

[15] Romm A.P.: Osnovnyye printsipy otsenki gorodskikh zemel'. Audit. Vedomosti, no. 12, 1998, pp. 11-14 [Ромм А.П.: Основные принциипь оценки городских земель. Аудит. Ведомости, № 12, 1998, с. 11-14].

[16] The Federal Service for State Registration, Cadastre and Cartography in Saint Petersburg [Федеральная служба государственной регистрации, кадастра и картографии по Санкт-Петербургу], [on-line:] https://rosreestr.ru/site/activity/kadastrovaya-otsenka/rassmotrenie-sporov-o-rezultatakh-opredeleniya-kadastrovoy-stoimosti-/informatsiya-o-deyatelnosti-komissiy-po-rassmotreniyu-sporov-o-rezultatakh-opredeleniya-kadastrovoy-/1informatsiya-o-deyatelnosti-komissiy-po-rassmotreniyu-sporov-o-rezultatakh-opredeleniya-kadastrovoy-2014/ [access: 29.01.2017].

[17] The Committee for Land Resources and Land Planning report about valuation of cadastral value of Saint Petersburg land plots (as updated in 12.08.2013) No. 32-1-0283/2012 [Отчет комитета по земельным ресурсам и землепользованию об оценке кадастровой стоимости земельных участков на территории Санкт-Петербурга (по состоянию на 12.08.2013 г.) № 32-1-0283/2012], [on-line:] http://www. to78.rosreestr.ru/kadastr/cadastral_estimation/rez_kad_ozem [access: 29.01.2017].

[18] Bykova Ye.N., Shabayeva Yu.I.: Prestizhnost' territorii i kontseptual'nyye polozheniya formirovaniya yeye kriteriyev. Izvestiya Sankt-Peterburgskogo gosudarstvennogo agrarnogo universiteta, no. 37, Sankt-Peterburg 2014, pp. 181-186 [Быкова Е.Н., Шабаева Ю.И.: Престижность территории и концептуальные положения формирования ее критериев. Известия Санкт-Петербургского государственного аграрного университета, № 37, Санкт-Петербург 2014, с. 181-186].

[19] Bykova Ye.N., Shabayeva Yu.I.: Metodika ranzhirovaniya territoriy naselennykh punktov po prestizhnosti. [in:] Geodeziya, kartografiya, geoinformatika i kadastry. Ot idei do vnedreniya. Sbornik materialov mezhdunarodnoy nauchno-prakticheskoy konferentsii. 11-13 noyabrya 2015 g., Politekhnika, Sankt-Peterburg 2015, pp. 166-171 [Быкова Е.Н., Шабаева Ю.И.: Методика ранжирования территорий населенных пунктов по престижности. [в:] Геодезия, картография, геоинформатика и кадастры. От идеи до внедрения. Сборник материалов международной научно-практической конференции. 11-13 ноября 2015 2., Политехника, Санкт-Петербург 2015, c. 166-171]. 


\section{Analiza porównawcza wyników wyceny katastralnej i rynkowej w Petersburgu}

Streszczenie: $W$ artykule przedstawiono analizę wyników katastralnej wyceny gruntów w Petersburgu. Wartości katastralne zostały porównywane z rzeczywistymi cenami rynkowymi działek. Badanie pozwoliło uzasadnić potrzebę wyceny gruntów na cele katastralne odrębnie dla różnych stref atrakcyjności miasta.

\section{Słowa}

kluczowe: wycena gruntów, rynek nieruchomości, analiza statystyczna, cena rynkowa, wartość katastralna 